\title{
Sarcoptes scabiei: genomics to proteomics to biology
}

\author{
Larry G. Arlian", Marjorie S. Morgan and S. Dean Rider Jr
}

\begin{abstract}
Background: The common scabies mite, Sarcoptes scabiei is a cosmopolitan parasite of humans and other mammals. An annotated genome of Sarcoptes scabiei var. canis has been deposited in the National Center for Biotechnology Information (NCBI) and VectorBase and a proteomic analysis of proteins in extracts of mite bodies and eggs from this strain has been reported. Here we mined the data to identify predicted proteins that are known to be involved in specific biological processes in other animals.

Results: We identified predicted proteins that are associated with immunomodulation of the host defense system, and biological processes of the mite including oxygen procurement and aerobic respiration, oxidative metabolism, sensory reception and locating a host, neuronal transmission, stressors (heat shock proteins), molting, movement, nutrient procurement and digestion, and excretion and water balance. We used these data to speculate that certain biological processes may occur in scabies mites.

Conclusion: This analysis helps understand the biology of Sarcoptes scabiei var. canis and adds to the data already available in NCBI and VectorBase.
\end{abstract}

Keywords: Sarcoptes scabiei, Scabies mite, Genome sequence, Biological processes

\section{Background}

The scabies mite, Sarcoptes scabiei, is a permanent obligate ectoparasite that lives and reproduces in the epidermis of skin of humans and many other mammalian hosts. Scabies is an important, neglected disease afflicting populations worldwide causing significant human and animal morbidity and mortality. Although there has been much progress in understanding the mite biology and interaction with its host, much is yet unknown.

A recent proteomic analysis of S. scabiei var. canis provided a listing of some of the proteins found in an aqueous extract of mite bodies, an extract of insoluble pellet of mite bodies, and an aqueous extract made from scabies mite eggs [1]. Likewise, the genome has been sequenced for this strain of S. scabiei [2]. The genomic and proteomic data are available at the National Center for Biotechnology Information (NCBI) and VectorBase. The genomic and proteomic data for specific aspects of the biology of this mite species provides a greater

\footnotetext{
* Correspondence: larry.arlian@wright.edu

Department of Biological Sciences, Wright State University, 3640 Colonel Glenn Hwy, Dayton, OH 45435, USA
}

(c) 2016 The Author(s). Open Access This article is distributed under the terms of the Creative Commons Attribution 4.0 International License (http://creativecommons.org/licenses/by/4.0/), which permits unrestricted use, distribution, and reproduction in any medium, provided you give appropriate credit to the original author(s) and the source, provide a link to the Creative Commons license, and indicate if changes were made. The Creative Commons Public Domain Dedication waiver (http://creativecommons.org/publicdomain/zero/1.0/) applies to the data made available in this article, unless otherwise stated.

\section{Methods}

We have previously reported the sequencing of DNA from the scabies mite, Sarcoptes scabiei var. canis, and the assembly of a draft genome for this organism [2]. All data for this project were deposited into the National Center for Biotechnology Information (NCBI) under BioProject PRJNA268368. Data are also available through VectorBase at www.vectorbase.org. Along with the draft genome, the sequences of 10,470 predicted Sarcoptes scabiei var. canis proteins were also deposited with accession numbers KPL93347 to KPM12096. The production of $>150$ of these predicted proteins was 
previously confirmed by mass spectrometry [1] and an additional 50 proteins have since been identified using identical methods.

Most of the data tables presented in this manuscript were constructed using keyword searches of the NCBI $S$. scabiei protein database which includes the $10,470 \mathrm{~S}$. scabiei var. canis sequences described above as well as $\sim 270$ additional sequences for proteins from scabies mites collected from other hosts (mostly humans and pigs). These searches returned hits when the keyword was part of the name assigned to the protein as well as when the keyword was found in the annotated record for a protein. For example, a search for "heme" returned both Heme peroxidase-like protein (where "heme" is in the name) and globin-like protein 1 (since the protein record indicates that a "heme-binding site" is part of the predicted structure). Proteins whose production was confirmed by mass spectrometry (MS) are noted in the supplementary tables (Additional file 1: Tables S1-S13).

BLAST2GO version 3.2 [3] was used to identify GO terms from interpro domains identified in all S. scabiei var. canis proteins that were not designated as "hypothetical" proteins in the proteome. These data are available in Additional file 2. GO terms grouped by biological process, cellular location, and molecular function were exported and used in keyword searches to help identify proteins of interest.

Molecular phylogenies generated for groups of related proteins utilized alignments generated by ClustalOmega (available at http://www.ebi.ac.uk/Tools/msa/clustalo/), followed by reconstructions of Neighbor Joining trees using ClustalW2 Phylogeny. Fig Tree v1.4.2 was used to render the phylogenetic tree images.

\section{Results and discussion Immunomodulation}

Molecules in extracts made from scabies mites have been shown to modulate the secretion or expression of cytokines, chemokines and cell adhesion molecules by cells of the epidermis and dermis of the skin and circulating blood lymphocytes [4-15], and inhibit the complement pathway of the host [16]. These data suggested that some aspects of this modulation delay the innate and adaptive immune responses to these mites and are responsible for the lack of clinical signs in the host for 4-8 weeks before skin symptoms are visible and patients seek diagnosis and treatment. Specifically, human peripheral blood mononuclear cells (PBMCs) stimulated with a whole body extract of scabies mites were shown to produce interleukin-10 (IL-10) but not IL-2 and IL-4 [9]. This cytokine profile suggested that the stimulated cell population consisted of T-regulatory (Treg) cells and not T-helper-1 (Th-1), Th-2, and Th-17 phenotypes.
Studies have shown that cystatin, a $14 \mathrm{kDa}$ protein in extracts of the parasitic round worm, Ascaris lumbricoides, up-regulated expression of IL-10 and transforming growth factor- $\beta$ (TGF $\beta$ ) from splenocytes from mice [17]. The genome for scabies mites contains two genes (QR98_0079060 and QR98_0079070) coding for cystatinlike proteins (KPM09372 and KPM09373) so it can be predicted that scabies mites may produce cystatin-like proteins and these proteins may be responsible for the up-regulated secretion of IL-10 observed from the Treg cells stimulated with a scabies mite extract. IL-10 is antiinflammatory and immune-suppressive and among other things, down-regulates a T-cell mediated immune response by depressing the expression of MHC II on the surface of antigen-presenting cells (APCs) and thus the interaction of the MHC II/antigen complex on the APCs with the T-cell receptor needed to stimulate T-helper cells.

Interestingly, several tick species including Ixodes scapularis, Dermacentor variabilis, Rhipicephalus microplus, Haemaphysalis longicornis and Ornithodoros moubata (soft tick) have predicted cystatin-like proteins with some homology $(<31 \%$ identity) to the scabies mite molecules (DELTA-BLAST search of KPM09372 and KPM09373 vs non-redundant protein sequences restricted to Acari, 16 Mar 2016). The two predicted scabies mite cystatin-like proteins also show limited (31\%) identity to each other. The gene for one of the predicted scabies mite proteins has a secretion signal (QR98_0079060).

Likewise, macrophage migration inhibitory factor (MIF) genes have been identified in both ticks and scabies mites $[2,18]$. MIF is a chemokine that regulates macrophage and other leukocyte migration [19]. A MIF gene from scabies mites has high nucleotide sequence homology with a MIF gene from the ticks $D$. variabilis, Amyblomma americanum and H. longicornis [18]. Although the gene nucleotide sequences differed slightly, the putative amino acid sequences for the scabies mite and the tick $D$. variabilis MIF proteins are identical.

Many genes for homologs of salivary gland proteins from ticks and other blood-sucking arthropods are present in the scabies mite genome [2]. These include ferritins, cathepsins, glutathione-S-transferases and thioredoxins. Genes for multiple tetraspanins that are involved in cell adhesion, cell migration and proliferation [20] are also present. Scabies mites have ten tetraspanin-like proteins and eight others with tetraspanin domains (Table 1). Scabies mites also have several genes that code for production of calmodulin-like proteins [2], which are calcium-binding proteins found in tick saliva [21]. The presence of many of these putative sialoproteins, including camodulins and calreticulin, in scabies mite body extracts was also verified by mass spectrometry [1]. 
Table 1 Sarcoptes scabiei var. canis proteins containing tetraspanin domains. Proteins were identified by $\mathrm{NBCl}$ protein database search of "Sarcoptes scabiei [and] tetraspanin" on 28 Mar 16

\begin{tabular}{lll}
\hline Name assigned to S. scabiei predicted protein & \# aa & Accession \# \\
\hline Tetraspanin-like protein 1 & 271 & KPM03168 \\
Tetraspanin-like protein 2 & 209 & KPM03650 \\
Tetraspanin-like protein 3 & 201 & KPM04223 \\
Tetraspanin-like protein 4 & 240 & KPM04224 \\
Tetraspanin-like protein 5 & 228 & KPM06000 \\
Tetraspanin-like protein 6 & 382 & KPM08766 \\
Tetraspanin-like protein 7 & 249 & KPM08935 \\
Tetraspanin-like protein 8 & 88 & KPM11003 \\
Tetraspanin-5-like protein & 338 & KPM02620 \\
Tetraspanin-11-like protein & 248 & KPM04544 \\
CD151 antigen-like protein & 148 & KPM06528 \\
CD63 antigen-like protein & 236 & KPM04484 \\
CD81 antigen-like protein & 288 & KPM04961 \\
Hypothetical protein QR98_0011670 & 152 & KPM02748 \\
Hypothetical protein QR98_0030280 & 252 & KPM04578 \\
Hypothetical protein QR98_0032560 & 272 & KPM04802 \\
Hypothetical protein QR98_0065550, partial & 302 & KPM08042 \\
Hypothetical protein QR98_0076100 & 176 & KPM09080 \\
\hline
\end{tabular}

\section{Oxygen requirements}

Scabies mites represent an unusual taxon of arthropods and metazoan animals that require oxygen (aerobic) but lack an organized respiratory system for obtaining it. They belong to the Astigmata group of Acari since no specialized surface or organ involved in oxygen uptake has yet been described or proposed. Scabies mites do not seem to have homologs for genes related to the known development of trachea that have been identified in Drosophila [22]. Interestingly, the scabies mite genome contains a homolog for the gene "scribbled" which in Drosophila promotes the development of both tracheae and salivary glands [22]. Apparently, the downstream genes representing the tracheal arm of this pathway are absent in scabies mites while the salivary gland pathway genes are present. In contrast, despite lacking the tracheapromoting genes identified in Drosophila, ticks and some other mites have tracheae $[23,24]$ so in some Acari there may be an alternative pathway for developing tracheae.

The oxygen requirements for scabies mites are low and were reported to be 0.002 and $0.0008 \mu \mathrm{l} \mathrm{O} / \mathrm{h}$ for female and male mites, respectively [25]. In comparison, the closely related astigmatid house dust mite, Dermatophagoides farinae, is of similar size and utilizes $0.009 \mu \mathrm{l}$ $\mathrm{O}_{2} / \mathrm{h}$ for females [26]. Neither the source nor the mechanism for obtaining oxygen is known for any of these astigmatid mites. In the case of house dust and storage mites that are terrestrial, the source of oxygen is most likely ambient air. It is not clear what the source of oxygen is for scabies mites while they are burrowing in the epidermis but presumably when they wander on the surface of the skin, they obtain oxygen from the ambient air. How much $\mathrm{O}_{2}$ is available in the burrow in the skin is unknown. If the mites ingest serum as they burrow, dissolved oxygen in this fluid could provide the oxygen they need along with nutrients. In humans, the partial pressure of oxygen in the arterial blood and serum in the surrounding tissues that bathes cells is about $100 \mathrm{mmHg}\left(0.003 \mu \mathrm{l} \mathrm{O}_{2} / \mu \mathrm{l}\right.$ fluid $)$ and drops to $40 \mathrm{mmHg}$ $\left(0.0012 \mu \mathrm{l} \mathrm{O}_{2} / \mu \mathrm{l}\right.$ fluid $)$ in venule blood. Could this be enough to meet their needs? These mites are too small to perform many physiological studies that would provide clues to how they obtain oxygen. Histology (electron microscopy) of both scabies and house dust mites provides no clues. However, genomic and proteomic data and associated genes and protein homologs that are associated with the process of obtaining oxygen and eliminating carbon dioxide in other organisms may provide some hints for these processes in scabies mites.

Regardless of how oxygen enters the mite body, scabies mites possess a wide variety of proteins typically involved in oxygen transport and utilization in other animals. Our analysis has predicted many proteins that may have an oxygen binding/transporting function in $S$. scabiei (Additional file 1: Table S1). Among these are more than 150 predicted proteins that contain heme, an oxygen-binding prosthetic group. Four genes code for globin proteins (QR98_0021760 = KPM03742 = globin-like protein 1; QR98_0035350=KPM05076= globinlike protein 2; QR98_0086180=KPM10070= cytoglobin1-like protein; and QR98_0042210=KPM05052 = neuroglobin-like protein) that could be involved in the transport of oxygen. The predicted proteome also contains a complete set of oxidative respiration (tricarboxylic acid cycle) enzymes (several of which were previously identified by MS) [1] as well as $>130$ enzymes involved in oxidative/reduction processes (Additional file 1: Table S2).

Thus, scabies mites require oxygen and they have many genes and predicted protein products associated with this requirement but the anatomy and biochemistry of getting $\mathrm{O}_{2}$ into the body and to the cells are unknown.

\section{Post-embryonic development/molting}

The life-cycle of scabies mites includes the egg, larva, protonymph, tritonymph and adult male or female [27]. Larvae hatch from eggs, feed, grow, undergo metamorphosis and molt to protonymphs. The process is repeated for protonymphs that give rise to tritonymphs and tritomymphs that give rise to adults. The molting process is well detailed for insects where it is regulated by ecdysteroids, and presumably, it is similar in mites. It 
involves digestion and reabsorption of some of the old cuticle (procuticle and endocuticle if both are present) and development of a new cuticle (procuticle) and varied degrees of sclerotization to harden the new procuticle. Hardening involves cross-linking of linear proteins and chitin molecules, the major components of the cuticle $[28,29]$. Chitin is a polymer of $\mathrm{N}$-acetyl-D-glucosamine molecules that are linked by $\beta-1,4$ covalent bonds. Chitin can be hydrolyzed by chitinase and exochitinase (or $\beta$ $\mathrm{N}$-acetylglucosaminidase) [30]. Chitin synthase promotes polymerization of the linear chitin molecule. Proteases hydrolyze the protein filaments. Many enzymes and biochemical pathways and several hormones are involved in the synthesis, translocation and degradation of the chitin and protein in the cuticle during the molting process. The scabies mite proteome contains 16 proteins that are predicted to serve as structural constituents of the cuticle (Table 2). This proteome also contains two chitin synthase-like proteins and four chitin deacetylase-like proteins (the latter catalyzes cleavage of acetate from the glucosamine molecule). In addition, there are 12 chitinase-like proteins, two (Sar s 15 and 18) that are homologs of house dust mite allergens (Additional file 1: Table S3). The scabies mite proteome also contains several glucosidases but it is unknown if they may play a role in degrading the cuticle. The genome also contains homologs of all of the enzymes known to be involved in ecdysteroidogenesis [31], indictating ecdysteroids are likely to regulate development in this mite (Table 3 ).

Table 2 Structural constituents of Sarcoptes scabiei var. canis cuticle. Proteins were identified by NBCl protein database search of "Sarcoptes scabiei [and] cuticle" on 11 Feb 16

\begin{tabular}{lll}
\hline Name assigned to S. scabiei predicted protein & \# aa & Accession \# \\
\hline Cuticle protein-like protein 1 & 104 & KPL98302 \\
Cuticle protein-like protein 2 & 663 & KPM03015 \\
Cuticle protein-like protein 3 & 168 & KPM06751 \\
Cuticle protein-like protein 4 & 404 & KPM08892 \\
Cuticle protein-like protein 5 & 225 & KPM10980 \\
Cuticle protein-like protein 6 & 341 & KPM10998 \\
Cuticle protein-like protein 7 & 314 & KPM11880 \\
Cuticular protein-like protein 9 & 160 & KPM09762 \\
Cuticular protein-like protein 8 & 360 & KPM02447 \\
Cuticular protein-like protein 10 & 189 & KPM09771 \\
Cuticular protein-like protein 11, partial & 245 & KPM10754 \\
Cuticle protein 57A-like protein 1 & 107 & KPM08966 \\
Cuticle protein 57A-like protein 2 & 189 & KPM08973 \\
Cuticle protein 92A-like protein & 121 & KPM08994 \\
Cuticle protein viking-like protein & 584 & KPM06292 \\
Structural constituent of cuticle-like protein & 214 & KPM09986 \\
\hline
\end{tabular}

Compounds that target and interfere with specific steps in the formation of the cuticle and the molting process have been developed for use as insecticides to control some insect species. As more is learned about these processes in mites and in particular scabies mites, specific aspects of these processes may be targets for developing new methods for controlling these mites on their hosts.

\section{Muscle physiology}

A general description of the mechanism for striated muscle activation and contraction can be found in many general physiology textbooks. Presumably scabies mites have striated muscles with morphology and contractile physiology similar to those of other arthropods and vertebrates. These would include actin and myosin protein fibers and the interaction sites involving dihydropyridine receptors, ryanodine receptors, calcium channels and pumps, tropomyosin, troponin subunits T, C, and I and calsequestrin. The fundamental mechanism based mostly on vertebrate studies, is that action potentials (depolarization), traveling into T-tubules mediated through dihydropyridine receptors and ryanodine receptors, cause opening of calcium channels in the sarcoplasmic reticulum (SR) membrane and the release of calcium from the SR into the myoplasm [32-34]. Activation of the actin and myosin contraction complex that results in sliding of the filaments to shorten the sarcomere (thus muscle), is calcium mediated and involves a calcium flux from the SR lumen into the myoplasm around the actin and myosin filaments. Relaxation of the muscle results from lower calcium concentration in the myoplasm by sequestration of calcium back into the SR. Lower calcium concentration in the myoplasm is accomplished by transmembrane proteins that pump calcium from the myoplasm back into the SR lumen where it binds to calsequestrin [35]. The presence of actin, myosin and tropomyosin in whole body extracts of scabies mites has already been confirmed by mass spectrometry [1]. The predicted proteome of scabies mites includes multiple actins (many of which may be involved in cytoskeletal movement) and myosins, tropomyosin, troponin $\mathrm{T}-, \mathrm{C}$ - and I-like proteins, ryanodine receptors, and numerous calcium pump proteins (Additional file 1: Table S4). Also, the scabies mite predicted proteome includes the calcium-binding proteins, calmodulin and calsequestrin-2-like proteins, as well. These proteins play a key role in sequestering calcium in the SR and in muscle contraction [35]. All this taken together is indirect evidence that muscle contraction and movement in scabies mites are accomplished by anatomy and contractile mechanisms that are similar to those used by insects, other arthropods and vertebrates. 
Table 3 Drosophila melanogaster genes involved in ecdysteroidogenesis and their predicted Sarcoptes scabiei var. canis gene and protein homologs. Adapted from [31]

\begin{tabular}{llll}
\hline D. melanogaster gene & S. scabiei gene homolog & Name assigned to S. scabiei predicted protein & Accession \# \\
\hline neverland & QR98_0055560 & Rieske domain-containing protein & KPM07074 \\
shroud & QR98_0023390 & 11-cis retinol dehydrogenase-like protein & KPM03900 \\
spook/spookier & QR98_0048390 & cytochrome P450-like protein 16 & KPM06364 \\
phantom & QR98_0078290 & cytochrome P450-like protein 20 & KPM09295 \\
disembodied & QR98_0104600 & cytochrome P450-like protein 26 & KPM11882 \\
shadow & QR98_0023200 & cytochrome P450-like protein 10 & KPM03882 \\
shadow & QR98_0044620 & cytochrome P450-like protein 15 & KPM05989 \\
shade & QR98_0022240 & cytochrome P450-like protein 9 & KPM03790 \\
\hline
\end{tabular}

\section{Calcium-binding proteins}

Approximately 143 calcium-binding proteins are predicted in the S. scabiei proteome and these are listed in Additional file 1: Table S5. Many such as calsequestrin and calmodulin, that are important in sequestration of calcium ions in the SR, are essential to muscle function and have already been mentioned. Another group appears to be low-density lipoprotein receptor-like proteins while many are hypothetical proteins of undetermined function.

\section{Heat shock proteins and others involved in protein folding and conformation}

Heat shock proteins (HSPs) are a large family of intracellular proteins that have multiple functions including acting as chaperones and maintaining the conformation and folding/unfolding of proteins, assembly of protein complexes, and transporting and sorting of proteins [36-38]. Each protein is designated by its molecular weight in kilodaltons. They are ubiquitous in organisms and are generally expressed when organisms encounter stressful conditions. HSPs with molecular weights, including 22, 23, 26, 27, 40, 60, 68, 70, 75, 78, 83 and 90, have been reported in a variety of insect species [37]. We found a large number of heat shock proteins in the proteome of scabies mites (Table 4) and the production of many of them has been confirmed by MS analysis [1]. Eight heat shock protein 70-like proteins (Sar s 28) are homologs of house dust mite allergens. HSP 10, 20, 60 and 90 family members are also present in the scabies mite proteome. This proteome also contains many other chaperone-type proteins (Additional file 1: Table S6).

Table 4 Sarcoptes scabiei var. canis heat shock proteins. Proteins were identified by NBCl protein database search of "Sarcoptes scabiei [and] heat shock" on 11 Feb 16

\begin{tabular}{lll}
\hline Name assigned to S. scabiei predicted protein & \# aa & Accession \# \\
\hline 10 kDa Heat shock protein, mitochondrial-like protein & 101 & KPM11276 \\
Heat shock protein 20-like protein 1 & 168 & KPM02991 \\
Heat shock protein 20-like protein 2 & 155 & KPM04326 \\
Heat Shock Protein 20-like protein 3 & 208 & KPM04511 \\
Heat Shock Protein 20-like protein 4 & 194 & KPM09528 \\
60 kDa Heat shock protein, mitochondrial-like protein & 584 & KPM06690 \\
Sar s 28 (heat shock protein 70-like protein 1) & 836 & KPL97880 \\
Sar s 28 (heat shock protein 70-like protein 2) & 634 & KPM03927 \\
Sar s 28 (heat shock protein 70-like protein 3) & 414 & KPM07069 \\
Sar s 28 (heat shock protein 70-like protein 4), partial & 496 & KPM07870 \\
Sar s 28 (heat shock protein 70-like protein 5) & 520 & KPM08853 \\
Sar s 28 (heat shock protein 70-like protein 6) & 703 & KPM10172 \\
Sar s 28 (heat shock protein 70-like protein 7) & 917 & KPM10783 \\
Sar s 28 (heat shock protein 70-like protein 8) & 567 & KPM11560 \\
Heat shock protein 90-like protein 1 & 587 & KPM03324 \\
Heat shock protein 90-like protein 2 & 469 & KPM07599 \\
Heat shock protein 90-like protein 3 & 796 & KPM09034 \\
\hline
\end{tabular}




\section{Neurotransmitters and receptors}

Incoming signals (chemo-, mechano-, photo-) travel along neurons as action potentials (APs). A membrane potential is maintained by the regulated pumping of sodium and potassium ions. Many sodium and potassium ion channel proteins have been predicted in the scabies mite proteome (Additional file 1: Table S7). Upon reaching the presynaptic membrane, the AP causes calcium channels to open and extracellular calcium diffuses into the neuron, which in turn triggers fusion of the synaptic vessel with the presynaptic membrane and the release of neurotransmitter that docks with the appropriate receptor on the postsynaptic membrane. There are four known classes of neural transmitters in insects: acetylcholine, biogenic amines, amino acids and peptides [39]. A gene for the receptor for the biogenic amine dopamine is present in the scabies mite genome (QR98_0022910). This neurotransmitter and GABA ( $\gamma$ - amino butyric acid) may play a role in salivary gland secretion in ticks $[40,41]$. Could it be involved in scabies mite salivary secretion as well? We have identified a number of specific receptors for various neurotransmitters in these classes in the predicted S. scabiei proteome (Additional file 1: Table S8). These neurotransmitter receptor proteins include those predicted to bind acetylcholine, nicotinic, dopamine, serotonin, GABA and neuropeptide Y. Because the scabies mite proteome includes these neural receptors, presumably, these mites utilize the corresponding neurotransmitters.

Sequencing of the scabies mite genome predicted the presence of a neuropeptide receptor in the somatostatin/ allatostatin family. In mammals, somatostatin is a peptide produced by neuroendrocrine neurons that has multiple functions including effecting neurotransmission [42]. Generally, it has inhibitory functions. Genes for the closely related neuropeptide allatostatins and their receptors have been found in the genome of the honeybee and in D. melanogaster and these share high homologies to somatostatin [43]. Allatostatins are thought to inhibit juvenile hormone synthesis in the honeybee brain. However, the presence of juvenile hormones in mites and ticks remains controversial [44]. Honeybee allatostatin [45] shares $\sim 36 \%$ identity with a hypothetical scabies mite protein (KPM07409). Thus, an allatostatin-like peptide hormone regulatory network probably also functions in S. scabiei, although its basic function remains unknown.

\section{Photoreception}

Ability to detect environmental stimuli is important to survival of S. scabiei. Laboratory studies show that scabies mites respond positively to thermo-, chemo- and odor stimuli and will seek the source [46]. These mites respond to light even though they have no visible simple eyes on their body surface like some species of mites.
However, simple light receptor cells could be located beneath the cuticle surface and stimulated when light passes through the clear cuticle. Opsin is a ubiquitous protein associated with light reception among most animals that respond to light. Opsin is coupled with the carotenoid light sensitive photopigment retinal to make the molecule rhodopsin [47]. Many predicted Gproteins, receptor-like proteins for rhodopsin and retinal, retinal degradation proteins, and molecules associated with the photochemistry of photoreception of electromagnetic radiation are present in the scabies mite proteome (Additional file 1: Table S9).

\section{Chemoreception}

A classic host-seeking study has clearly shown that mites respond to host odor and are attracted to its source [46]. Several previous studies have also shown that scabies mites are attracted to 17 lipids that are present in or on the epidermis of mammalian skin [48]. Likewise, scabies mites are attracted by the odor from a host independent of body heat or contact with the skin and its various chemical components and physical properties [46]. Presumably these attractions facilitate location of a host and/or guide mites to specific areas of the host body.

In addition, our previous study revealed that scabies mites are attracted to several nitrogenous wastes and phenolic compounds that act in a pheromone-like manner and induce aggregation of these mites [49]. Ticks secrete nitrogenous wastes and phenolic compounds that act in a pheromone like-manner to promote assembly and other behavior [50]. The test methods used for the scabies mite behavior studies were not designed to determine the purpose of this assembly, but it may play a key role in attraction of sexes for mating. Early and ordinary scabies infestations involve few mites on the host so mite produced nitrogen wastes such as guanine, purine, adenine, allantoin, hypoxanthine, xanthine, uric acid, ammonium chloride, ammonium nitrate and ammonium sulfate and pheromones, likely play key roles in the reproduction of scabies mites during this time. The fact that scabies mites respond to these compounds indicates that they have chemoreceptors that recognize the volatile and contact compounds.

Taken together, all of these studies have shown that $S$. scabiei var. canis must have chemoreceptors. Like insects, it is expected that mites have odorant (OR), gustatory (GR) and ionotropic (IR) chemoreceptors. In the insects, and probably the Acari, chemoreceptors are usually located in hollow pegs or setae known as sensilla that are located on the antenna, terminal segments of the legs (tarsus), proboscis/mouthparts, wing margins, ovipositor and possibly pedipalps [51, 52]. Typically, these sensilla are perforated along the sides or at the tip and this allows stimulant molecules from the air (odor/ 
pheromones) or contact (gustatory) to enter hemolymph in the sensilla bathing the neuron and bind to an odorant/tastant-binding protein that transports the stimulating molecule to the sensory receptor on the neuron [51]. The odorant/transporting complex or the released stimulant molecule activates the sensory receptor. Mites have hollow sensilla on the terminal segments of the legs that presumably function in a similar manner. It is not known if the oral cavity has chemoreceptors beneath the cuticle lining or if there are chemoreceptors on the pretarsal stocked empodia, chelicera, pedipalps and other body areas of scabies and other mites.

A scabies mite protein database search identified 13 predicted proteins that may be involved in chemoreception (Table 5). These include various sweet-taste receptor-like proteins, and a gustatory receptor-like protein. Our analysis of S. scabiei predicts fewer chemoreceptors in scabies mites than are reported in the genomes of some bloodsucking insects but approximately the same as for the body louse Pediculus humanus corporis. For example, the bedbug, Cimex lectularius, has genes coding for 49 olfactory receptors, 36 gustatory receptors and 30 ionotropic receptors [53]. The tsetse fly, Glossina morsitans morsitans, has 46 and 14 annotated gene loci for ORs and GRs, respectively [54]. The mosquitoes, Anopheles gambiae and Aedes aegypti, have many more ORs and GRs than both the tsetse flies and scabies mites. The genome for the human body louse contains ten odorant receptor genes [55].

Previous studies showed that scabies mites respond to host odor in the absence of carbon dioxide [46]. Whether or not $\mathrm{CO}_{2}$ by itself will arouse activity in scabies mites has not been determined. $\mathrm{CO}_{2}$ from a host is a stimulus for blood feeding mosquitoes and other insects $[56,57]$ and ticks [50]. Chemosensory neurons in
Drosophila that are $\mathrm{CO}_{2}$-sensitive express the chemoreceptors Gr21a and Gr63a. The An. gambiae mosquito homologs are GPPRGR22 and GPRRGR24 [58]. The scabies mite predicted proteome does not have orthologs of the $\mathrm{CO}_{2}$ receptors from insects. Thus, if $\mathrm{CO}_{2}$ sensing occurs in scabies mites it utilizes an unknown pathway. However, scabies mites will seek a host in the absence of $\mathrm{CO}_{2}$. Genes for $\mathrm{CO}_{2}$ receptors have not been identified in the tick genome even though ticks do respond to $\mathrm{CO}_{2}$.

The family of ionotropic receptors can be located on post-synaptic membranes and form ion channels. These receptors have an extracellular domain that binds the neurotransmitter and other domains that cross the membrane and form the ion channel [59]. When activated by the neurotransmitter, the flow of ions through the pore is either increased or decreased. The scabies mite genome has 16 predicted "ionotropic receptor proteins" (Table 6). In contrast, bedbugs have 30 predicted ionotropic receptors [53], 24 of which have significant homology with 15 different $S$. scabiei var. canis proteins (Additional file 1: Table S10).

\section{Proteases and other enzymes}

In a previous study, we used a variety of assays to characterize some of the enzymatic activities present in aqueous extracts of nine species of astigmatid mites [60]. Of the mite species tested, S. scabiei had the most limited enzymatic repertoire. Phosphatase, phosphohydrolase, esterase, aminopeptidase and glycosidase activities were detected in the scabies mite extract and proteins predicted to carry out these catalytic activities are all present in the proteome (Additional file 1: Table S11). Esterase lipase (C8) activity was detected in the

Table 5 Sarcoptes scabiei var. canis proteins predicted to be involved in chemoreception. Proteins were identified by NBCI protein database search of "Sarcoptes scabiei [and] taste [or] sensory" on 1 Mar 16

\begin{tabular}{|c|c|c|}
\hline Name assigned to S. scabiei predicted protein & \# аa & Accession \# \\
\hline 7 transmembrane sweet-taste receptor-like protein 1 & 140 & KPM05630 \\
\hline 7 transmembrane sweet-taste receptor-like protein 2 & 321 & KPM06440 \\
\hline 7 transmembrane sweet-taste receptor-like protein 3, partial & 385 & KPM09849 \\
\hline Class C metabotropic glutamate-like protein G-protein coupled receptor-like protein & 187 & KPM06441 \\
\hline Gamma-aminobutyric acid type B receptor subunit 1-like protein, partial & 861 & KPM06518 \\
\hline Glutamate receptor, metabotropic-like protein 2 & 164 & KPM11384 \\
\hline Gustatory receptor-like protein & 441 & KPM04823 \\
\hline Metabotropic glutamate receptor 1-like protein 1, partial & 429 & KPM05105 \\
\hline Metabotropic glutamate receptor-like protein 3 & 526 & KPM07738 \\
\hline Metabotropic glutamate receptor-like protein 4 & 476 & KPM08699 \\
\hline Pheromone and odorant receptor-like protein & 1650 & KPM05712 \\
\hline Sensory neuron membrane protein 1-like protein & 346 & KPM11235 \\
\hline Sweet-taste receptor-like protein & 429 & KPM09147 \\
\hline
\end{tabular}


Table 6 Sarcoptes scabiei var. canis ionotropic receptors. Proteins were identified by NBCl protein database search of "Sarcoptes scabiei [and] ionotropic" on 24 Mar 16

\begin{tabular}{|c|c|c|}
\hline Name assigned to S. scabiei predicted protein & \# аa & Accession \# \\
\hline Glutamate receptor, ionotropic kainate 2 precursor-like protein 1 & 147 & KPM04302 \\
\hline Glutamate receptor, ionotropic kainate 2 precursor-like protein 2 & 465 & KPM04471 \\
\hline Glutamate receptor, ionotropic kainate 2-like protein 1 & 298 & KPM02574 \\
\hline Glutamate receptor, ionotropic kainate 2-like protein 2 & 652 & KPM04300 \\
\hline Glutamate receptor, ionotropic kainate 2-like protein 3 & 887 & KPM05200 \\
\hline Glutamate receptor, ionotropic kainate 2-like protein 4 & 357 & KPM05378 \\
\hline Glutamate receptor, ionotropic kainate 3-like protein 1 & 1102 & KPL94547 \\
\hline Glutamate receptor, ionotropic kainate 3-like protein 2 & 883 & KPM06129 \\
\hline Glutamate receptor, ionotropic kainate-like protein 1, partial & 746 & KPM03138 \\
\hline Glutamate receptor, ionotropic kainate-like protein 2 & 553 & KPM05237 \\
\hline Glutamate receptor, ionotropic, kainate-like protein 3 & 180 & KPM04472 \\
\hline Glutamate receptor, ionotropic, N-methyl D-aspartate-associated protein 1-like protein & 223 & KPM05160 \\
\hline Ionotropic kainate 2-like protein glutamate receptor-like protein & 651 & KPM04303 \\
\hline Kainate-selective ionotropic glutamate receptor-like protein 1, partial & 461 & KPL97052 \\
\hline Kainate-selective ionotropic glutamate receptor-like protein 2 & 234 & KPM04473 \\
\hline Kainate-selective ionotropic glutamate receptor-like protein 3 & 1141 & KPM09535 \\
\hline
\end{tabular}

extract while lipase (C14) activity was not even though the proteome is predicted to contain at least 20 lipaselike proteins of varying specificity.

Our previous study also failed to detect either chymotrypsin or trypsin catalytic activity in the scabies mite extract, a finding that was consistent with previous reports for other ectoparasites [61-63]. This is interesting since the S. scabiei var. canis proteome is predicted to contain one chymotrypsin-like protein and at least 13 trypsin-like serine proteases and ten serine proteaselike proteins in addition to 18 serine protease-like proteins that are dust mite Group 3 allergen homologs (Sar s 3) (Additional file 1: Table S12).

Scabies mites collected from human patients have previously been reported to possess a single, active Sar s 3 homolog and 16 structurally similar proteins (designated as Scabies Mite Inactivated Protease Paralogs or SMIPP-S) in which the catalytic triad is mutated so as to make them inactive [64]. The active protease is reported to be a digestive enzyme that is able to partially digest filaggrin, a protein found in human skin [65], while some of the inactive paralogs can inhibit the human complement system, presumably playing a role in allowing the parasite to evade the host's immune defense systems [16]. Examination of the structures predicted for the various serine proteases of S. scabiei var. canis revealed that only five of 13 trypsin-like serine proteases, five of 10 serine protease-like proteins and two of the 18 Sar s 3 serine protease-like proteins had intact catalytic triads while the other members of these three groups of proteins had mutations similar to those in the SMIPP-S proteins (Additional file 1: Table S13). Phylogenetic comparisons of the Sar s 3 homologs from both human and dog scabies mites indicated that the sequences in both lineages that contain an active catalytic triad are derived from a common ancestral gene (Fig. 1). The remaining inactive protease genes appear to have undergone duplications and acquired inactivating mutations both before and after the split between the two mite lineages. Additionally, most of the mutant S. scabiei var. canis proteins did have intact substrate-binding sites. In the case of the ten predicted Sar s 1 cysteine proteaselike proteins, five (KPM05039 - KPM05043) had intact catalytic triads and were orthologs of previously-reported Sar s 1 proteins (AAS93667-AAS93671) [66], suggesting an ancient and essential function for these five proteins (Fig. 2). The other five Sar s 1 family members had mutations in the catalytic triad like those in the SMIPP-C protein group, but the relationships of the S. scabiei var. canis homologs to those found in human scabies mites suggest that both recent and ancient duplications have occurred in the two scabies mite lineages.

The strain of scabies mites used to prepare the draft genome has been shown to be resistant to the acaricide permethrin [67, 68]. High levels of various detoxifying enzymes can be responsible for pesticide resistance in arthropods and we previously demonstrated that these mites had higher levels of esterase, cytochrome P450 monooxygenase and glutathione S-transferase (GST) activities than were present in permethrin-sensitive $S$. scabiei mites [68]. In addition to the esterases described above, these mites also are likely capable of producing 


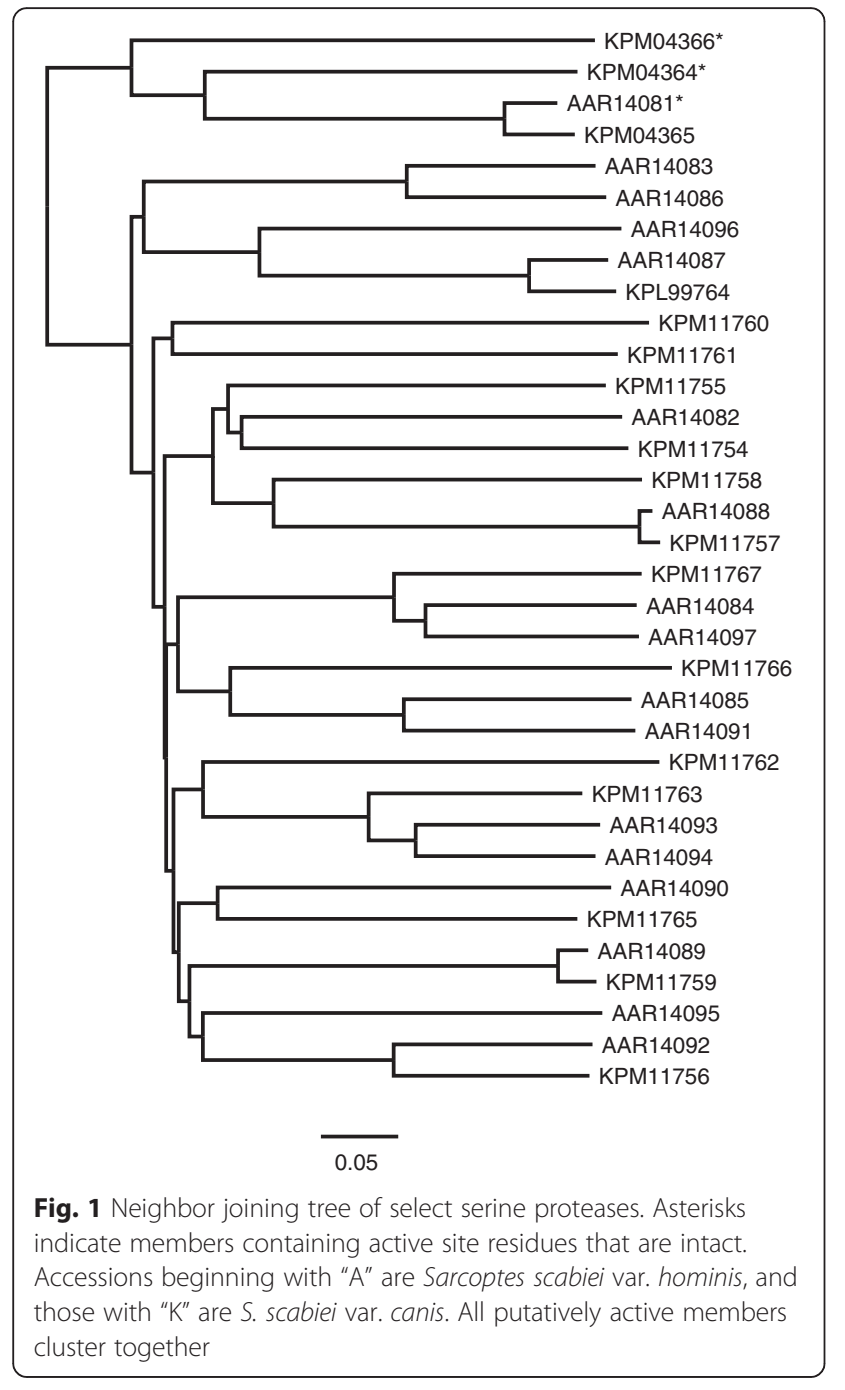

26 cytochrome P450-like proteins (Additional file 1: Table S2) and a variety of GSTs (Table 7).

In addition to the various enzymatic activities described above, scabies mites also appear to be able to synthesize the enzymes required to catalyze the vast spectrum of anabolic and catabolic reactions that are required by multicellular aerobic organisms (Additional file 2).

\section{Peritrophic membrane in the midgut}

The peritrophic membrane in the insect and mite midgut protects the mucosa and may play a role in digestion. It contains a chitin and peritrophin protein complex. This membrane is sloughed as undigested food passes out of the midgut and it forms a membrane around (encapsulates) the fecal pellets. The fecal pellets can be seen in skin scrapes from scabietic patients and are an important observation for the diagnosis of this disease. We found at least 30 peritrophin homologs including a variety of proteins that contain the chitin-

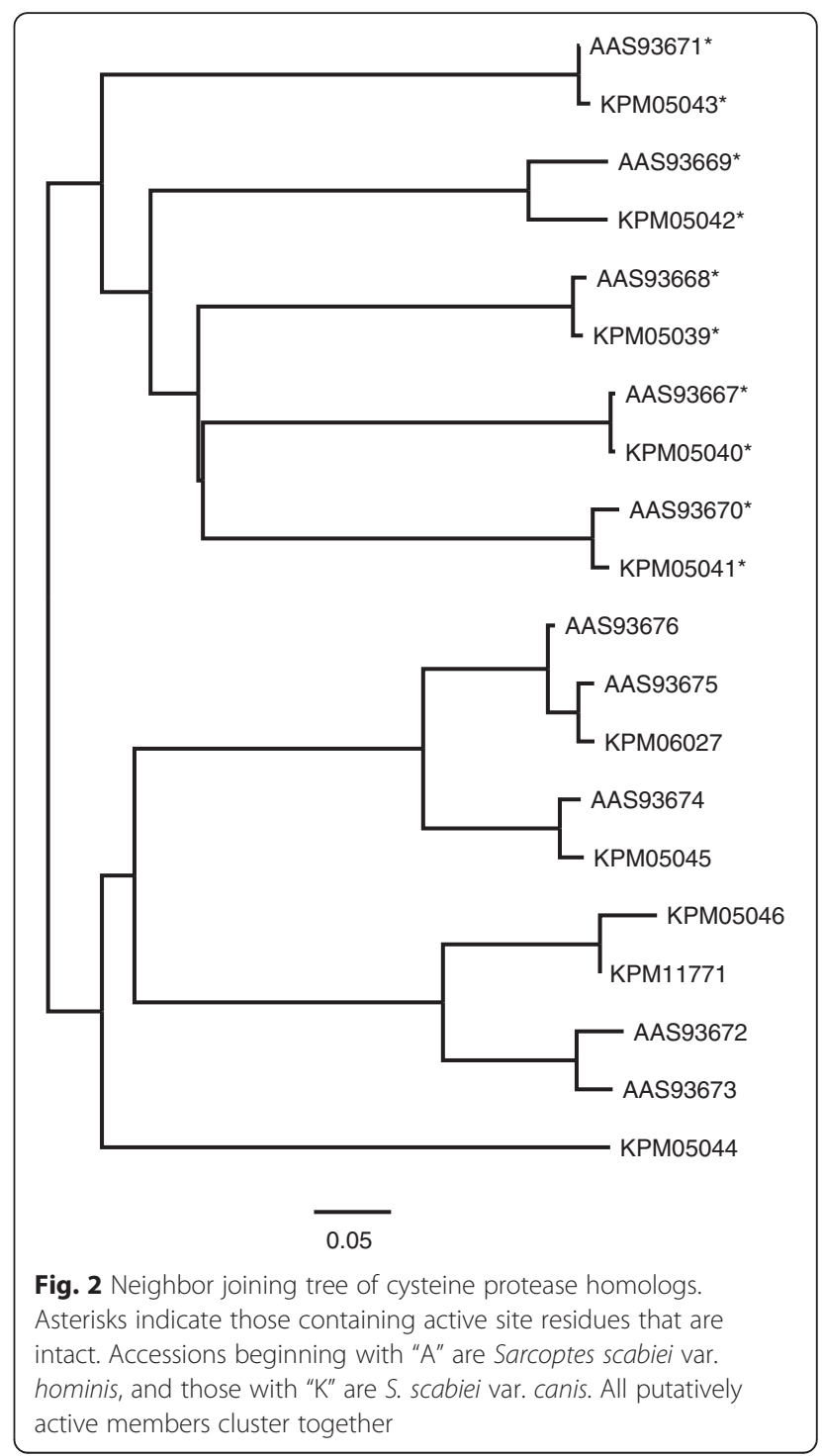

binding peritrophin-A domain (Table 8). One protein containing this chitin-binding domain is a homolog of the Group 23 dust mite allergens (Sar s 23). These proteins seem to provide evidence that even though S. scabiei may consume primarily a liquid diet of serum and digested epidermal stratum corneum, the peritrophic membrane (along with many digestive enzymes) has an important function in nutrient procurement, digestion and defecation in these mites.

\section{Aquaporins/water balance and transport}

Aquaporins are a family of transmembrane proteins that form pores through which water can flow in and out of cells and they are found in many different tissues and are in most organisms [69-73]. Aquaporins are essential components of the excretory system in Malpighian tubules of insects where they regulate water and solute 
Table 7 Sarcoptes scabiei var. canis glutathione S-transferases (GSTs). Proteins were identified by NBCl protein database search of "Sarcoptes scabiei [and] glutathione" on 22 Apr 16

\begin{tabular}{lll}
\hline Name assigned to S. scabiei predicted protein & \# aa & Accession \# \\
\hline Glutathione S transferase-like protein 1 & 227 & KPM02265 \\
Glutathione S transferase-like protein 2 & 265 & KPM02492 \\
Glutathione S transferase-like protein 3 & 210 & KPM03123 \\
Glutathione S transferase-like protein 4 & 236 & KPM03124 \\
Glutathione S transferase-like protein 5 & 383 & KPM11027 \\
Glutathione S-transferase delta class 3 & 221 & KPM09608 \\
Glutathione S-transferase-like protein & 227 & KPM02264 \\
Sar s 8 allergen (Glutathione S transferase mu-like protein 1) & 262 & KPM02280 \\
Sar s 8 allergen (Glutathione S transferase mu-like protein 2) & 200 & KPM11584 \\
Sar s 8 allergen (Glutathione S transferase mu-like protein 3) & 219 & KPM11585 \\
Sar s 8 allergen (Glutathione S transferase mu-like protein 4) & 219 & KPM11586 \\
Sar s 8 allergen (Glutathione S transferase mu-like protein 5) & 219 & KPM11587 \\
\hline
\end{tabular}

concentrations $[69,73]$. The scabies mite genome encodes two complete aquaporin genes, and fragments for three others were identified in the assembly. One of the complete genes encodes a traditional aquaporin (QR98_0011640 = KPM02745), while the second encodes an aquaglyceroporin (QR98_0057420 = KPM07253). It is likely that these proteins regulate both water balance and solute movement in this mite, concentrating nitrogenous waste in the Malpighian tubules and processing it for elimination.

\section{Excretion of nitrogenous wastes}

Nitrogenous waste products are produced from the metabolism of proteins and purines. The nitrogenous waste produced by an organism is generally related to its solubility and the availability of water. In terrestrial ticks and mites, nitrogenous waste is shunted through the purine metabolism pathway, where guanine and xanthine are major waste products [74-76]. In S. scabiei var. canis, the gene for guanosine monophosphate synthase is present, which would allow the conversion of xanthosine monophosphate into guanosine monophosphate. Genes are also present for the multistep conversion of these monophosphates into their respective nucleobases through a purine nucleoside intermediate, or via the single step conversion to a nucleobase using phosphoribosyltransferases (Table 9). However, genes for guanine deaminase, which converts guanine to xanthine, were not found. Additionally, genes encoding xanthine dehydrogenase/oxidase were also not found. Thus, $S$. scabiei probably lacks the ability to produce urate. The pathway in Ixodes ticks (based on genomic information) is the same, thus the presence of guanine and xanthine in excrement likely results from the separate metabolism of the respective monophosphates, rather than the conversion of guanine to xanthine.

\section{Conclusions}

Most biological processes in the scabies mite are not understood. Here, we have mined the draft S. scabiei var. canis genome and associated proteome in an attempt to identify homologs of genes and proteins already recognized to have known functions in some physiological processes in other animals. We have restricted this search to those genes and predicted proteins that are associated with basic biological processes or requirements. We were particularly interested in genes that encode for proteins known to be associated with vital biological processes such as immune modulation, obtaining oxygen for aerobic respiration and oxidative metabolism, sensory reception and locating a host, neuronal transmission, stressors (heat shock proteins), molting, movement, excretion and water balance, nutrient procurement and digestion. We have not attempted to identify gene groups coding for enzymes and proteins associated with the many anabolic and catabolic processes and biochemical pathways such as 2nd messenger signaling, regulation of gene expression, transcription, translation, Golgi and mitochondrial function, energy metabolism, endocrine system function and hormone synthesis, secretion, etc.

This research is obviously limited by the data that are already available for other organisms in the public databases. At this time there are 23350 S. scabiei var. canis genes without orthologs in other mite species and $\sim 4100$ predicted proteins in scabies mites identified as "hypothetical" since they have no matches in any database. This does not mean that all these genes and proteins are unique to scabies mites although some probably are. As more genomes for other animals and in particular arthropods are sequenced and the data made available, the list of unassigned genes and proteins will likely shrink. For now, we are able to use the available data to speculate on some biological processes for scabies mites that may help understand their biology. 
Table 8 Sarcoptes scabiei var. canis proteins containing a peritrophin domain. Proteins were identified by $\mathrm{NBCl}$ protein database search of "Sarcoptes scabiei [and] peritrophin" on 20 Apr 16

\begin{tabular}{|c|c|c|}
\hline Name assigned to S. scabiei predicted protein & \# аa & Accession \# \\
\hline Chitin binding Peritrophin-A domain containing protein 1 & 101 & KPM02161 \\
\hline Chitin binding Peritrophin-A domain containing protein 2 & 387 & KPM03068 \\
\hline Chitin binding Peritrophin-A domain containing protein 3, partial & 1167 & KPM03793 \\
\hline Chitin binding Peritrophin-A domain containing protein 4, partial & 379 & KPM06347 \\
\hline Chitin binding Peritrophin-A domain containing protein 5, partial & 452 & KPM07124 \\
\hline Chitin binding Peritrophin-A domain containing protein 6 & 346 & KPM07304 \\
\hline Chitin binding Peritrophin-A domain containing protein 7 & 222 & KPM07429 \\
\hline Chitin binding Peritrophin-A domain containing protein 8 & 174 & KPM07489 \\
\hline Chitin binding Peritrophin-A domain containing protein 9 & 309 & KPM08965 \\
\hline Chitin binding Peritrophin-A domain containing protein 10 , partial & 583 & KPM09937 \\
\hline Chitin binding Peritrophin-A domain containing protein 11 & 93 & KPM11506 \\
\hline Chitin binding peritrophin-A-like protein 2 & 149 & KPM09480 \\
\hline Chitin deacetylase-like protein 3 & 514 & KPM11442 \\
\hline Chitinase-like protein 1, partial & 1236 & KPM05982 \\
\hline Chitinase-like protein 4 & 259 & KPM08718 \\
\hline Chitinase-like protein 10 , partial & 653 & KPM11497 \\
\hline Hypothetical protein QR98_0026710 & 691 & KPM04228 \\
\hline Hypothetical protein QR98_0028980 & 485 & KPM04450 \\
\hline Hypothetical protein QR98_0029710 & 290 & KPM04522 \\
\hline Hypothetical protein QR98_0036850 & 289 & KPM05225 \\
\hline Hypothetical protein QR98_0037360 & 256 & KPM05275 \\
\hline Hypothetical protein QR98_0041930 & 348 & KPM05724 \\
\hline Hypothetical protein QR98_0049080, partial & 700 & KPM06433 \\
\hline Hypothetical protein QR98_0065480 & 368 & KPM08035 \\
\hline Hypothetical protein QR98_0075900 & 185 & KPM09060 \\
\hline Hypothetical protein QR98_0086540 & 318 & KPM10104 \\
\hline Peritrophin & 486 & AEA34990 \\
\hline Peritrophin-like protein & 186 & KPM09194 \\
\hline Sar s 15 allergen (chitinase-like protein) & 571 & KPM07813 \\
\hline Sar s 23 allergen (chitin binding domain containing protein) & 92 & KPM09573 \\
\hline Vesicle coat complex COPII, subunit SFB3-like protein & 230 & KPM03439 \\
\hline
\end{tabular}

Table 9 Sarcoptes scabiei var. canis genes and proteins predicted to be involved in nitrogenous waste production

\begin{tabular}{lll}
\hline Gene locus & Predicted protein function & Accession \# \\
\hline QR98_0098200 & GMP synthase & KPM11250 \\
QR98_0088290 & 5' nucleotidase & KPM10277 \\
QR98_0037400 & 5' nucleotidase & KPM05279 \\
QR98_0082120 & 5' nucleotidase & KPM09671 \\
QR98_0000820 & 5' nucleotidase & KPL94019 \\
QR98_0039780 & 5' nucleotidase & KPM05513 \\
QR98_0057060 & Purine nucleoside phosphorylase & KPM07218 \\
QR98_0020510 & Phosphoribosyltransferase & KPM03618 \\
QR98_0100210 & Hypoxanthine-guanine phosphoribosyltransferase & KPM11451 \\
\hline
\end{tabular}




\section{Additional files}

Additional file 1: Tables S1-S13. Complete results of the various database searches described in the text. (XLSX $101 \mathrm{~kb}$ )

Additional file 2: BLAST2GO results generated on 25 Feb 2016 as described in the Methods. Data are sorted alphabetically by GO Biological Process. (XLSX $192 \mathrm{~kb}$ )

\section{Acknowledgements}

The authors wish to thank Dr. Joshua Benoit of the University of Cincinnat for providing the amino acid sequences used in the analysis presented in Additional file 1: Table S10.

\section{Funding}

Research reported in this publication was supported by the National Institute of Allergy and Infectious Diseases of the National Institutes of Health under Award Number R01Al017252. The content is solely the responsibility of the authors and does not necessarily represent the official views of the National Institutes of Health.

\section{Availability of data and materials}

Data for this project were deposited into the National Center for Biotechnology Information (NCBI) under BioProject PRJNA268368 and are also available through VectorBase at www.vectorbase.org. All other pertinent data are included in the manuscript and accompanying Additional files 1 and 2 .

\section{Authors' contributions}

LGA conceived the study. SDR and MSM performed the computer searches and organized the data. LGA, MSM and SDR interpreted the data and prepared the manuscript. All authors read and approved the final manuscript.

\section{Competing interests}

The authors declare that they have no competing interests.

\section{Consent for publication}

Not applicable.

\section{Ethics approval and consent to participate}

Not applicable.

Received: 4 May 2016 Accepted: 22 June 2016

Published online: 01 July 2016

\section{References}

1. Morgan MS, Arlian LG, Rider SD, Jr, Grunwald WC, Jr, Cool DR. A proteomic analysis of Sarcoptes scabiei (Acari: Sarcoptidae). J Med Entomol. 2016; doi: 10.1093/jme/tjv247

2. Rider SD, Morgan MS, Arlian LG. Draft genome of the scabies mite. Parasite Vector. 2015;8:585-98.

3. Conesa A, Gotz S, Garcia-Gomez JM, Terol J, Talon M, Robles M. Blast2GO: a universal tool for annotation, visualization and analysis in functional genomics research. Bioinformatics. 2005;21(18):3674-6.

4. Morgan MS, Arlian LG, Markey MP. Sarcoptes scabiei mites modulate gene expression in human skin equivalents. PLoS One. 2013;8:e71143. doi:10. 1371/journal.pone.0071143.

5. Morgan MS, Arlian LG. Response of human skin equivalents to Sarcoptes scabiei. J Med Entomol. 2010:47:877-83.

6. Lalli PN, Morgan MS, Arlian LG. Skewed Th1/Th2 immune response to Sarcoptes scabiei. J Parasitol. 2004:90(4):711-4.

7. Arlian LG, Morgan MS, Neal JS. Extracts of scabies mites (Sarcoptidae: Sarcoptes scabiei) modulate cytokine expression by human peripheral blood mononuclear cells and dendritic cells. J Med Entomol. 2004:41(1):69-73.

8. Elder BL, Arlian LG, Morgan MS. Sarcoptes scabiei (Acari: Sarcoptidae) mite extract modulates expression of cytokines and adhesion molecules by human dermal microvascular endothelial cells. J Med Entomol. 2006; 43(5):910-5.

9. Arlian LG, Morgan MS, Paul CC. Evidence that scabies mites (Acari: Sarcoptidae) influence production of interleukin-10 and the function of T-regulatory cells (Tr1) in humans. J Med Entomol. 2006;43(2):283-7.
10. Arlian LG, Fall N, Morgan MS. In vivo evidence that Sarcoptes scabiei (Acari: Sarcoptidae) is the source of molecules that modulate splenic gene expression. J Med Entomol. 2007;44(6):1054-63.

11. Mullins JS, Arlian LG, Morgan MS. Extracts of Sarcoptes scabiei De Geer downmodulate secretion of IL-8 by skin keratinocytes and fibroblasts and of GM-CSF by fibroblasts in the presence of proinflammatory cytokines. J Med Entomol. 2009;46(4):845-51.

12. Elder BL, Arlian LG, Morgan MS. Modulation of human dermal microvascular endothelial cells by Sarcoptes scabiei in combination with proinflammatory cytokines, histamine, and lipid-derived biologic mediators. Cytokine. 2009; 47(2):103-11. doi:10.1016/j.cyto.2009.05.008.

13. Stemmer BL, Arlian LG, Morgan MS, Rapp CM, Moore PF. Characterization of antigen presenting cells and T-cells in progressing scabietic skin lesions. Vet Parasitol. 1996;67(3-4):247-58.

14. Arlian LG, Vyszenski-Moher DL, Rapp CM, Hull BE. Production of IL-1 alpha and IL-1 beta by human skin equivalents parasitized by Sarcoptes scabiei. J Parasitol. 1996;82(5):719-23.

15. Arlian LG, Morgan MS, Neal JS. Modulation of cytokine expression in human keratinocytes and fibroblasts by extracts of scabies mites. Am J Trop Med Hyg. 2003;69(6):652-6.

16. Bergstrom FC, Reynolds S, Johnstone M, Pike RN, Buckle AM, Kemp DJ, et al. Scabies mite inactivated serine protease paralogs inhibit the human complement system. J Immunol. 2009;182(12):7809-17. doi:10.4049/ jimmunol.0804205.

17. Coronado SM, Barrios L, Zakzuk J, Franco L, Caraballo L. Recombinant Cystatin from Ascaris lumbricoides has immunomodulatory effects. J Allergy Clin Immunol. 2016;137:AB228.

18. Cote NM, Jaworski DC, Wasala NB, Morgan MS, Arlian LG. Identification and expression of macrophage migration inhibitory factor in Sarcoptes scabiei. Exp Parasitol. 2013;135:175-81. doi:10.1016/j.exppara.2013.06.012.

19. Grieb G, Merk M, Bernhagen J, Bucala R. Macrophage migration inhibitory factor (MIF): a promising biomarker. Drug News Perspect. 2010;23:257-64. doi:10.1358/dnp.2010.23.4.1453629.

20. Jiang $X$, Zhang J, Huang Y. Tetraspanins in cell migration. Cell Adh Migr. 2015:1-10; doi:10.1080/19336918.2015.1005465.

21. Radulovic ZM, Kim TK, Porter LM, Sze SH, Lewis L, Mulenga A. A 24-48 h fed Amblyomma americanum tick saliva immuno-proteome. BMC Genomics. 2014;518:518-2164-15-518. doi:10.1186/1471-2164-15-518.

22. Isaac DD, Andrew DJ. Tubulogenesis in Drosophila: a requirement for the trachealess gene product. Genes Dev. 1996;10(1):103-17.

23. Woolley TA. Acarology: mites and human welfare. New York: Wiley; 1988.

24. Edwards KT, Goddard J, Varela-Stokes A. Examination of the internal morphology of the ixodid tick Amblyomma maculatum Koch (Acari: Ixodidae); a "how-to" pictorial dissection guide. Midsouth Entomologist. 2009:2(3):28-39.

25. Arlian LG, Ahmed M, Vyszenski-Moher DL, Estes SA, Achar S. Energetic relationships of Sarcoptes scabiei var. canis (Acari: Sarcoptidae) with the laboratory rabbit. J Med Entomol. 1988;25(1):57-63.

26. Arlian LG. Water exchange and effect of water vapour activity on metabolic rate in the dust mite, Dermatophagoides. J Insect Physiol. 1975;21(8):1439-42.

27. Arlian LG, Vyszenski-Moher DL. Life cycle of Sarcoptes scabiei var. canis. J Parasitol. 1988;74(3):427-30.

28. Andersen SO. Cuticle. In: Resh VH, Cardé RT, editors. Encyclopedia of insects. Amsterdam; Boston: Academic; 2009. p. 245-6.

29. Daly HV, Doyen JT, Purcell AH. Introduction to insect biology and diversity. 2nd ed. Oxford; New York: Oxford University Press; 1998.

30. Cohen E. Chitin. In: Resh VH, Cardé RT, editors. Encyclopedia of insects. Amsterdam; Boston: Academic; 2009. p. 156-7.

31. Niwa R, Niwa YS. Enzymes for ecdysteroid biosynthesis: their biological functions in insects and beyond. Biosci Biotechnol Biochem. 2014; 78(8):1283-92.

32. Lanner JT, Georgiou DK, Joshi AD, Hamilton SL. Ryanodine receptors: structure, expression, molecular details, and function in calcium release. Cold Spring Harb Perspect Biol. 2010:2(11):a003996. doi:10.1101/cshperspect.a003996.

33. Zalk R, Clarke OB, Des Georges A, Grassucci RA, Reiken S, Mancia F, et al. Structure of a mammalian ryanodine receptor. Nature. 2015:517(7532):44-9. doi:10.1038/nature13950

34. Hill RW, Wyse GA, Anderson M. Chapter 20: Muscle. In: Anonymous animal physiology. Sunderland, Mass: Sinauer Associates, Inc. Publishers; 2012. p. 524-66.

35. Yanez M, Gil-Longo J, Campos-Toimil M. Calcium binding proteins. Adv Exp Med Biol. 2012;740:461-82. doi:10.1007/978-94-007-2888-2_19. 
36. Bakthisaran R, Tangirala R, Rao C. Small heat shock proteins: Role in cellular functions and pathology. Biochim Biophys Acta. 2015;1854(4):291-319. doi:10.1016/j.bbapap.2014.12.019.

37. King AM, MacRae TH. Insect heat shock proteins during stress and diapause Annu Rev Entomol. 2015;60:59-75. doi:10.1146/annurev-ento-011613-162107.

38. Li Z, Srivastava P. Heat-shock proteins. Curr Protoc Immunol. 2004; Appendix 1:Appendix $1 \mathrm{~T}$; doi:10.1002/0471142735.ima01ts58.

39. Chapman RF. The insects: structure and function. 4th ed. Cambridge; New York: Cambridge University Press; 1998.

40. Sauer JR, Essenberg RC, Bowman AS. Salivary glands in ixodid ticks: control and mechanism of secretion. J Insect Physiol. 2000;46(7):1069-78. doi: S0022191099002103 [pii].

41. Simo L, Zitnan D, Park Y. Neural control of salivary glands in ixodid ticks. J Insect Physiol. 2012;58(4):459-66. doi:10.1016/j.jinsphys.2011.11.006.

42. Liu Y, Lu D, Zhang Y, Li S, Liu X, Lin H. The evolution of somatostatin in vertebrates. Gene. 2010;463(1-2):21-8. doi:10.1016/j.gene.2010.04.016.

43. Urlacher E, Soustelle L, Parmentier ML, Verlinden H, Gherardi MJ, Fourmy D, et al. Honey bee allatostatins target galanin/somatostatin-like receptors and modulate learning: A conserved function? PLoS One. 2016;11(1):e0146248. doi:10.1371/journal.pone.0146248.

44. Rees HH. Hormonal control of tick development and reproduction. Parasitology. 2004;129(Suppl):S127-43

45. Hummon $A B$, Richmond $T A$, Verleyen $P$, Baggerman $G$, Huybrechts J, Ewing $M A$, et al. From the genome to the proteome: uncovering peptides in the Apis brain. Science. 2006;314(5799):647-9.

46. Arlian LG, Runyan RA, Sorlie LB, Estes SA. Host-seeking behavior of Sarcoptes scabiei. J Am Acad Dermatol. 1984;11(4 Pt 1):594-8.

47. Randall DJ, Burggren WW, French K, Eckert R. Eckert animal physiology: mechanisms and adaptations. 5th ed. New York: Freeman; 2002.

48. Arlian LG, Vyszenski-Moher DL. Response of Sarcoptes scabiei var. canis (Acari: Sarcoptidae) to lipids of mammalian skin. J Med Entomol. 1995; 32(1):34-41.

49. Arlian LG, Vyszenski-Moher DL. Responses of Sarcoptes scabiei (Acari: Sarcoptidae) to nitrogenous waste and phenolic compounds. J Med Entomol. 1996;33(2):236-43

50. Sonenshine DE. Pheromones and other semiochemicals of ticks and their use in tick control. Parasitology. 2004;129(Suppl):S405-25.

51. Leal WS. Odorant reception in insects: roles of receptors, binding proteins, and degrading enzymes. Annu Rev Entomol. 2013;58:373-91. doi:10.1146/annurev-ento-120811-153635.

52. Montell C. A taste of the Drosophila gustatory receptors. Curr Opin Neurobiol. 2009;19(4):345-53. doi:10.1016/j.conb.2009.07.001.

53. Benoit JB, Adelman ZN, Reinhardt K, Dolan A, Poelchau M, Jennings EC, et al. Unique features of a global human ectoparasite identified through sequencing of the bed bug genome. Nat Commun. 2016;7:10165. doi:10.1038/ncomms10165.

54. Obiero GF, Mireji PO, Nyanjom SR, Christoffels A, Robertson HM, Masiga DK. Odorant and gustatory receptors in the tsetse fly Glossina morsitan morsitans. PLoS Negl Trop Dis. 2014;8(4):e2663. doi:10.1371/journal. pntd.0002663

55. Kirkness EF, Haas BJ, Sun W, Braig HR, Perotti MA, Clark JM, et al. Genome sequences of the human body louse and its primary endosymbiont provide insights into the permanent parasitic lifestyle. Proc Natl Acad Sci U S A. 2010;107:12168-73. doi:10.1073/pnas.1003379107.

56. Kellogg FE. Water vapour and carbon dioxide receptors in Aedes aegypti. J Insect Physiol. 1970;16(1):99-108.

57. Gillies MT. The role of carbon dioxide in host-finding by mosquitoes (Diptera: Culicidae): a review. Bull Entomol Res. 1980;70:525-32. doi:10.1146/annurev.en.19.010174.002021.

58. Jones WD, Cayirlioglu P, Kadow IG, Vosshall LB. Two chemosensory receptors together mediate carbon dioxide detection in Drosophila. Nature. 2007;445(7123):86-90.

59. Rytz R, Croset V, Benton R. lonotropic receptors (IRs): chemosensory ionotropic glutamate receptors in Drosophila and beyond. Insect Biochem Mol Biol. 2013;43(9):888-97. doi:10.1016/j.ibmb.2013.02.007.

60. Morgan MS, Arlian LG. Enzymatic activity in extracts of allergy-causing astigmatid mites. J Med Entomol. 2006;43(6):1200-7.

61. Nisbet AJ, Billingsley PF. Hydrolytic enzymes of Psoroptes cuniculi (Delafond). Insect Biochem Mol Biol. 1999;29(1):25-32.

62. Nisbet AJ, Billingsley PF. A comparative survey of the hydrolytic enzymes of ectoparasitic and free-living mites. Int J Parasitol. 2000;30(1):19-27.
63. Kenyon F, Knox D. The proteinases of Psoroptes ovis, the sheep scab mite-their diversity and substrate specificity. Vet Parasitol. 2002; 105(4):317-25.

64. Holt DC, Fischer K, Allen GE, Wilson D, Wilson P, Slade R, et al. Mechanisms for a novel immune evasion strategy in the scabies mite Sarcoptes scabiei: a multigene family of inactivated serine proteases. J Invest Dermatol. 2003; 121(6):1419-24. doi:10.1046/j.1523-1747.2003.12621.x.

65. Beckham SA, Boyd SE, Reynolds S, Willis C, Johnstone M, Mika A, et al. Characterization of a serine protease homologous to house dust mite group 3 allergens from the scabies mite Sarcoptes scabiei. J Biol Chem. 2009;284:34413-22. doi:10.1074/jbc.M109.061911.

66. Holt DC, Fischer K, Pizzutto SJ, Currie BJ, Walton SF, Kemp DJ. A multigene family of inactivated cysteine proteases in Sarcoptes scabiei. J Invest Dermatol. 2004;123(1):240-1. doi:10.1111/j.0022-202X.2004.22716.X.

67. Pasay C, Arlian L, Morgan M, Vyszenski-Moher D, Rose A, Holt D, et al. Highresolution melt analysis for the detection of a mutation associated with permethrin resistance in a population of scabies mites. Med Vet Entomol. 2008;22(1):82-8. doi:10.1111/j.1365-2915.2008.00716.x.

68. Pasay C, Arlian L, Morgan M, Gunning R, Rossiter L, Holt D, et al. The effect of insecticide synergists on the response of scabies mites to pyrethroid acaricides. PLoS Negl Trop Dis. 2009;3(1):e354. doi:10.1371/journal.pntd. 0000354.

69. Campbell EM, Ball A, Hoppler S, Bowman AS. Invertebrate aquaporins: a review J Comp Physiol B. 2008;178(8):935-55. doi:10.1007/s00360-008-0288-2.

70. de Groot BL, Grubmuller H. Water permeation across biological membranes: mechanism and dynamics of aquaporin-1 and GlpF. Science. 2001; 294(5550):2353-7. doi:10.1126/science.1062459.

71. Takata K, Matsuzaki T, Tajika Y. Aquaporins: water channel proteins of the cell membrane. Prog Histochem Cytochem. 2004;39(1):1-83.

72. Hubert JF, Thomas D, Cavalier A, Gouranton J. Structural and biochemical observations on specialized membranes of the "filter chamber", a watershunting complex in sap-sucking homopteran insects. Biol Cell. 1989; 66(1-2):155-63.

73. Spring JH, Robichaux SR, Hamlin JA. The role of aquaporins in excretion in insects. J Exp Biol. 2009;212(Pt 3):358-62. doi:10.1242/jeb.024794.

74. Schmidt G, Liss M, Thannhauser SJ. Guanine, the principal nitrogenous component of the excrements of certain spiders. Biochim Biophys Acta. 1955;16(4):533-5.

75. Pauli G, Hoyet C, Tenabene A, le Mao J, Thierry R, Bessot JC. Guanine and mite allergenicity in house dust. Clin Allergy. 1988;18(4):383-92.

76. Sonenshine DE, Adams T, Allan SA, McLaughlin J, Webster FX. Chemical composition of some components of the arrestment pheromone of the black-legged tick, Ixodes scapularis (Acari: Ixodidae) and their use in tick control. J Med Entomol. 2003:40(6):849-59.

\section{Submit your next manuscript to BioMed Central and we will help you at every step:}

- We accept pre-submission inquiries

- Our selector tool helps you to find the most relevant journal

- We provide round the clock customer support

- Convenient online submission

- Thorough peer review

- Inclusion in PubMed and all major indexing services

- Maximum visibility for your research

Submit your manuscript at www.biomedcentral.com/submit 